\title{
女子学生の骨量に与える身体状況及び食物摂取状況の影響
}

\author{
山本由喜子* · 柴尾知志和** · 田中順子*** \\ $\left(*\right.$ 大阪市立大学大学院, ${ }^{* *}$ 大阪市立大学, ${ }^{* * *}$ 大阪信愛女学院短期大学 $)$
}

\section{Effects of Physical Properties and Eating Habits on Bone Mass in Female Students}

\author{
Yukiko Yamamoto*, Chishiwa Shibao**, Yoriko Tanaka*** \\ ${ }^{*}$ Graduate School of Human Life Science, Osaka City University, 3 - 3 -138 Sugimoto, Sumiyoshi-ku, Osaka 558- \\ 8585 Japan \\ **Faculty of Human Life Science, Osaka City University, 3 - 3 -138 Sugimoto, Sumiyoshi-ku, Osaka 558-8585 Japan \\ ***Department of Human Life Science, Osaka, Shin-Ai College, 2-7-30 Furuichi, Joto-ku, Osaka, 536-8585 Japan
}

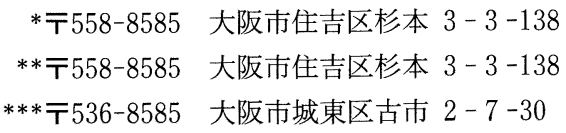

The effects of the eating habits and physical properties of female students, and the effects of the eating habits of their mothers, on their bone mass were studied. The bone mass of 50 female students aged 18-21 yrs. was measured by ultrasound methods. Current dietary intake was measured based on a quantitative dietary record for 3 days. The present and past eating habits of the students (primary school-high school) and of their mothers at present were assessed by a questionnaire regarding their food preferences and intake frequency. The subjects were divided into three groups based on their bone mass, which is significantly different from each other. The three groups separated by bone mass were significantly different from each other with respect to the preference and intake frequency of milk and milk products in past and present, and the intake frequency of small fish in the past. The difference between the three groups based on the current intake of energy and nutrients, physical characteristics including their body weight and body mass index (BMI), exercise habits, age of menarche and duration from menarche was not significant.

These results suggested that the preference and intake frequency of milk and milk products and the intake frequency of small fish in the past are important for obtaining a higher bone mass by female students.

\section{1. 緒言}

骨粗彭症は閉経期以降の女性に発症しやすい疾患で, 近年の急速な高齢化に伴い患者数が急激に增加してい
る，骨粗鬆症の発症は腰痛，骨折，さらに寝たきりの原 因となって，高秢者のQOLを著しく損なうことから社 会的問題となっている.加齢による骨量変化については, 青年期までに骨量が最も高くなって最大骨量に達し1) 4), 
その後, 加齢とともに減少し, 特に閉経期には急激に減 少することが観察されている5)。 そこで骨粗鬆症の発症 予防には, 高龄期に抢ける骨量減少を抑制することに加 えて, 青年期までにより高い最大骨量を獲得することが 有効と考えられている. またさらに，青・壮年期に抢け る生活習慣からくる骨量減少を抑制することも骨粗鬆症 の予防に重要と考えられる.

しかし，近年，我が国では食生活の多様化とともに簡 略化傾向が強まり, それにともなう弊害が懸念されるよ うになってきた，忺食や夜食の増加，食事時間の不規則 化, 外食·調理済反食品 · 加工食品への依存度の増大, などの傾向が，特に若年期で顕著であることが指摘され ている ${ }^{6)}$. 女性については, やせ志向, 低栄養傾向など が指摘され ${ }^{6), 7)}$ ， また若年期女性の低栄養状態が低骨量 化の危険因子として懸念されている。このような状況に おいて, 青年期における骨量を測定し，また生活習慣上 の問題点を明らかにしてその改善を計ることは, 将来の 骨粗鬆症を予防するうえで重要なことである.

骨量の測定は, 骨粗鬆症検診が平成 7 年に老人保健法 による基本審査の中に取り入れられたこともあり,近年, 全国的に普及している，骨量測定は現在，X線フィルム を用いる方法, X線ビームを用いる方法, 超音波を用い る方法などさまざまな測定法が実用化されているが，検 診の目的と条件に応じて測定法と測定部位が決定されて いる. 踵骨超音波測定法 (quantitative ultrasound 法 ; QUS 法) は踵骨の骨量を超音波をあてることにより求 めるもので, 放射線被爆からの安全性, 可搬性, 測定の 簡便性などの点で優れており，骨折のリスクを評洒する マススクリーニングに有用である。 また，求められた結 果は，X線を用いて測定する二重エネルギーX線吸収度 計法（dual X-ray absorptiometry 法; DXA 法）の結果

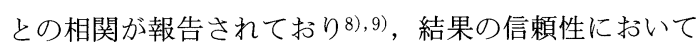
も評価しうると考えられている.

骨量に影響する因子としては, 栄養・食品拄取状況10) 19), 運動習慣(10), 15) 17), 20)，体重などの身体状況(10),12),16)など 多様な因子が考えられている．しかし，それらの諸要因 が骨の発育に影響することについて必ずしも一致した結 果が得られておらず，その詳細は十分に解明されている とはいえない,さらに, 青年期の食生活状況や栄養摂取 状況は, その成長期に抢ける状況や養育者の意識などの 影響を受けていると予想されるが，そのような点につい ての研究はあまりみられない，そこで本研究では，女子 学生の骨量をQUS 法により測定し, 現在ならびに過去 （小学生〜高校生）における栄養摂取ならびに食物摂取
状況, 運動習慣, 初経などの生理状況, 身体状況などと の関連性を検討し，さらに親の食物嫩好性や食物摂取頻 度との関連性についても検討した。

\section{2. 方法}

\section{1. 調査対象および調査時期}

大阪府内の生活学系の大学, 短期大学に在籍する女子 学生 55 人, 抢よびその家庭に扔ける調理担当者（本人を 除く）を対象とした. 実施時期は2001年 7 月であった.

\section{2. 食物摂取状況の調査}

食物摄取状況に関するアンケート調査を質問紙法によ り実施した結果, 調査対象者 55 人のうち 50 人より回答が 得られ, 回収率は $91 \%$ であった。 また, 調理担当者は 48 人より回答が得られ，回収率は $87 \%$ であった，調査内容 は，12種類の食品の嗜好度および摄取頻度である，嗜好 度は「好き」「やや好き」「ふつう」「やや嫌い」「嫌い」 の 5 段階とし, 便宜的にそれぞれ 5 点, 4 点, 3 点, 2 点， 1 点として平均得点を算出した．また，掟取頻度は 「毎日食べる」「 2 日に 1 回」「 3 日に 1 回」「 1 週間に 1 回」「ほどんぞ食べない」の 5 段階とし，同様にそれぞ れ 5 点, 4 点, 3 点, 2 点, 1 点として平均得点を算出 した. 女子学生については, 現在ならびに過去（小学校 から高等学校) の食物摂取状況を調査した. 女子学生本 人および調理担当者用の調査用紙は自宅に持ち帰らせ, それぞれ本人に記入してもらったものを回収した．調理 担当者の内訳は母親 45 人 (94\%), 祖母 3 人 (6\%) で, 大多数が母親であったので以後母親と称した.

\section{3. 栄養摄取状況の調査}

食生活状況に関するアンケート調査の回答が得られた 女子学生 50 人の栄養素等摄取量を, 調査期間中の平日 3 日間の秤量法による食事記録から測定し, エクセル栄養 君（Ver 3.0, 建帛社）により求めた.

\section{4. 骨量の測定}

食生活状況に関するアンケート調査の回答が得られた 女子学生 50 人の右踵骨骨量を超音波骨評価装置 (アロカ (侏，AOS-100）により測定し，超音波伝播速度（SOS; speed of sound）と透過指標（TI; transmission index） から求めた音響的骨評価値 (OSI; osteo sono-assessment index）で骨量を表した.

\section{5. 年齢 - 身体状況および運動量の調査}

年路, 身長, 体重, 初経年齢, 初経後の経過期間を自 記式調査用紙にて調査した。

現在の運動量は, 調查期間の 3 日間の歩数を歩数計で 測定した平均值を用いた，過去の運動習慣は，小学校か 


\section{日本食生活学会誌}

ら高等学校の期間の運動経験についてアンケート調査を 行い,「毎日」「 1 週間に $3 \sim 5$ 日」「 1 週間に $1 \sim 2$ 日」 「なし」の 4 段階をそれぞれ 4 点, 3 点, 2 点, 1 点と して平均得点を算出した。

\section{6. 統計処理}

データの解析には, 米国 SPSS 社の統計ソフト SPSS （Ver. 6.1 for the Macintosh）を用いた. 項目間の関連 性を調べるため各カテゴリーにつきクロス集計表を作成 し, グループ間の差をみるために Kruskal-Wallis の順 位和検定を行った. また Pearson 相関係数または Spearman 相関係数を求めて相関分析を行った.

\section{3. 結果および考察}

\section{1. 調査対象者の特性ならびに骨量}

調査対象者の年龄, 身長, 体重, BMI，および骨量 測定の結果は Table 1 のようであった. BMI の平均值 は19.6で, 国民栄養調査結果の 20 29歳女性の平均値 $20.5^{6)}$ より低值であった。 また $18.5>$ のやせの学生は14

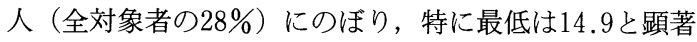
に低値であった。

Table 1 Characteristics of study subjects and their bone mass (OSI)

\begin{tabular}{lcc}
\hline & mean $\pm \mathrm{SE}$ & $($ min.-max. $)$ \\
\hline Age (years) & $19.1 \pm 0.8$ & $(18-21)$ \\
Height $(\mathrm{cm})$ & $158.5 \pm 6.4$ & $(145-171)$ \\
Weight $(\mathrm{kg})$ & $49.3 \pm 5.9$ & $(38-69)$ \\
$\mathrm{BMI}\left(\mathrm{kg} / \mathrm{m}^{2}\right)^{1)}$ & $19.6 \pm 1.8$ & $(14.9-24.3)$ \\
$\mathrm{OSI}{ }^{2}$ & $2.62 \pm 0.24$ & $(1.98-3.26)$ \\
\hline $\mathrm{n}=50$ & \\
${ }^{1)} \mathrm{BMI}$, body mass index. \\
${ }^{2)}$ OSI, osteo sono-assessment index.
\end{tabular}

OSI の平均值は $2.619 \pm 0.241$ であった。これは老人保 健法の骨粗鬆症予防マニュアルによるマススクリーニン グのための判定基準，すなわち20歳から44歳までの健常 女性6,096例の平均值2.698 $00.298^{21)}$ の $97.1 \%$ であった. 同マニュアルのマススクリーニングにおいては，基準 值の $80 \%$ （2.158）未満の場合は要精検レベル， $90 \%$ （2.428）未満の場合は要指導レベルと診断される.この 基準に基づくと, 本研究の対象者のうち 1 人が要精検レ ベル, 8 人が要指導レベルに相当した.

調査対象者をOSIにより 3 群に分類した（Fig. 1). OSI がスクリーニングのための判定基準值の $100 \%$ 以上 をA群，90\%以上で100\%未満をB群，90\%末満をC 群

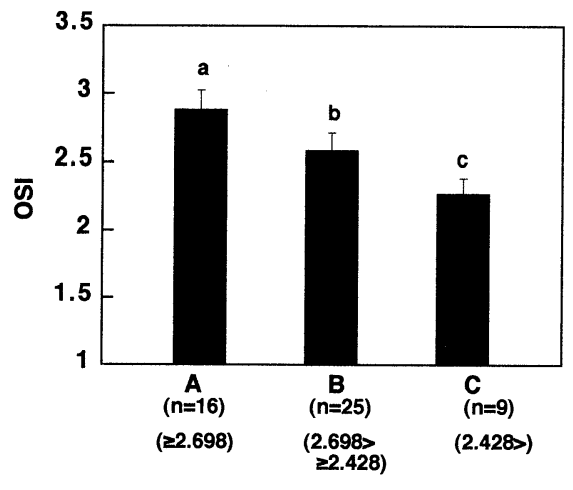

Fig. 1 Bone mass in subjects

Study subjects were separated in three groups on the bone mass measured by OSI (osteo sono-assessment index); $\mathrm{A}, \geqq 2.698$; $\mathrm{B}, 2.698>$, $\geqq 2.428 ; \mathrm{C}, 2.428>$. Mean $\pm \mathrm{SE}$, data with different superscripts are significantly different from each other (Kruskal -Wallis test, $\mathrm{p}<0.05$ ).

とした場合 A，B，C群に相当するものはそれぞれ16， $25 ， 9$ 人であった， A， B， C群の平均 OSI 值はそれ ぞれ $2.876 \pm 0.038,2.578 \pm 0.017,2.274 \pm 0.045 て ゙, こ$ れらの間には相互に有意差が認められた。

\section{2. 栄養素等摂取状況と骨量の関係}

エネルギーならびに各栄養素の平均摂取量の結果と， 年齢別, 性別, 生活強度別の相当する所要量 (RDA) および目標值を Table 2 に示した. エネルギー，カルシ ウム, 鉄, マグネシウムの摂取量は所要量を充たさず, 特にエネルギ一摂取量は所要量の $83 \%$ にすぎなかった. また，食物繊維摂取量は著しく低值で目標值の $65 \%$ 以下 であった。一方，脂肪摂取量は所要量をはるかに超え， タンパク質摂取量も所要量を超えていた。このような低 いエネルギー摂取と高い脂肪の摄取は，国民栄養調査に おける 20 歳代女性の特徴 ${ }^{6)}$ と一致しており, さらに低い 食物繊維摂取と併せて, 調査対象者の栄養摂取上の問題 点を示していた.

エネルギーならびに各栄養素の摂取量とOSI の関連 を調べた結果, Table 2 に示すように，それらの間には 有意な相関はみられなかった．また対象者をOSI 值に より区分した $\mathrm{A}, \mathrm{B}, \mathrm{C} の 3$ 群についてエネルギーなら びに各栄養素の摂取量を比較した結果でも，いずれの摂 取量も 3 群間に有意差が見られなかった. 栄養素摂取量 と骨の発育については, カルシウム摂取量が相関するこ とが多くの研究で認められている10),12),13),16),19)が，一 方, 相関を認めないとする結果も報告されている18). 本 研究ではカルシウム摂取量と骨量の間に有意な関連性は 
Table 2 Intake of energy and nutrients

\begin{tabular}{|c|c|c|c|c|c|c|c|c|}
\hline & \multirow[t]{2}{*}{$\mathrm{RDA}^{1)}$} & \multirow[t]{2}{*}{ Intake } & \multicolumn{2}{|c|}{$\begin{array}{l}\text { Correlation between } \\
\text { OSI and intake of } \\
\text { energy or nutrients }\end{array}$} & \multicolumn{4}{|c|}{$\begin{array}{c}\text { Intake of energy and nutrients in groups } \mathrm{A}, \mathrm{B} \\
\text { and } \mathrm{C}\end{array}$} \\
\hline & & & $\mathrm{r}^{*}$ & $p^{* *}$ & $\mathrm{~A}$ & $\mathrm{~B}$ & $\mathrm{C}$ & $p^{* * *}$ \\
\hline Energy（kcal） & 2050 & $1705 \pm 48$ & -0.158 & $\mathrm{~ns}$ & $1678 \pm 132$ & $1699 \pm 57$ & $1760 \pm 90$ & $\mathrm{~ns}$ \\
\hline Fat $(\%)^{2)}$ & $20-25$ & $29.8 \pm 0.7$ & 0.091 & $\mathrm{~ns}$ & $29.3 \pm 0.5$ & $29.7 \pm 0.8$ & $30.8 \pm 0.7$ & $\mathrm{~ns}$ \\
\hline Protein $(\mathrm{g})$ & 55 & $63.8 \pm 2.5$ & -0.035 & $\mathrm{~ns}$ & $63.7 \pm 6.8$ & $63.8 \pm 3.0$ & $64.1 \pm 4.4$ & $\mathrm{~ns}$ \\
\hline Calcium (mg) & 600 & $552 \pm 31$ & 0.005 & ns & $556 \pm 68$ & $572 \pm 44$ & $490 \pm 51$ & ns \\
\hline Phosphorus (mg) & 700 & $965 \pm 36$ & -0.031 & ns & $972 \pm 26$ & $998 \pm 38$ & $857 \pm 40$ & ns \\
\hline Iron $(\mathrm{mg})$ & 12 & $7.3 \pm 0.3$ & 0.066 & ns & $7.2 \pm 0.2$ & $7.6 \pm 0.4$ & $7.0 \pm 0.3$ & $\mathrm{~ns}$ \\
\hline $\mathrm{NaCl}(\mathrm{g})$ & $\leqq 10$ & $8.2 \pm 0.3$ & -0.148 & ns & $7.9 \pm 0.7$ & $8.2 \pm 0.5$ & $8.7 \pm 0.6$ & ns \\
\hline Magnesium (mg) & 250 & $221 \pm 8.1$ & 0.042 & $\mathrm{~ns}$ & $223 \pm 6.1$ & $229 \pm 8.4$ & $196 \pm 7.2$ & $\mathrm{~ns}$ \\
\hline Vitamin D $(\mu \mathrm{g})$ & 2.5 & $7.4 \pm 1.0$ & -0.006 & $\mathrm{~ns}$ & $7.8 \pm 1.6$ & $7.1 \pm 1.4$ & $7.8 \pm 2.0$ & $\mathrm{~ns}$ \\
\hline Vitamin $\mathrm{K}(\mu \mathrm{g})$ & 55 & $219 \pm 21$ & -0.024 & ns & $217 \pm 21$ & $216 \pm 21$ & $230 \pm 21$ & $\mathrm{~ns}$ \\
\hline Vitamin C (mg) & 100 & $140 \pm 29$ & -0.015 & ns & $144 \pm 22$ & $137 \pm 30$ & $145 \pm 27$ & ns \\
\hline Dietary fiber $(\mathrm{g})$ & $20-25$ & $12.9 \pm 0.6$ & 0.050 & ns & $13.2 \pm 0.5$ & $12.7 \pm 0.6$ & $13.3 \pm 0.6$ & $\mathrm{~ns}$ \\
\hline
\end{tabular}

Intake values are mean $\pm \mathrm{SE}$.

${ }^{1)}$ Recommended dietary allowance for 18-29 year old Japanese females (activity index 3).

2) (Energy intake from fat) / (Total energy intake) $\times 100$.

${ }^{*}$ Correlation coefficients (Pearson correlation) and ${ }^{* *}$ probability, ns means not significant.

***Probability with Kruskal-Wallis test.

Table 3 Scores of preference and eating frequency of foods of students at present and past time and difference between three groups separated according to their OSI

\begin{tabular}{|c|c|c|c|c|c|c|c|c|}
\hline & \multicolumn{4}{|c|}{ Past (primary school $\sim$ high school) } & \multicolumn{4}{|c|}{ Present } \\
\hline & A & $\mathrm{B}$ & $\mathrm{C}$ & $p^{*}$ & A & $\mathrm{B}$ & $\mathrm{C}$ & $p^{*}$ \\
\hline \multicolumn{9}{|l|}{ Preference $^{1)}$} \\
\hline Milk and milk products & $4.3 \pm 0.2^{3)}$ & $4.1 \pm 0.2$ & $3.5 \pm 0.2$ & $<0.05$ & $4.5 \pm 0.2$ & $4.4 \pm 0.2$ & $3.8 \pm 0.2$ & $<0.05$ \\
\hline Soybean and soybean products & $3.4 \pm 0.2$ & $3.8 \pm 0.3$ & $3.4 \pm 0.2$ & ns & $3.9 \pm 0.3$ & $4.0 \pm 0.2$ & $4.1 \pm 0.3$ & ns \\
\hline Vegetable & $4.1 \pm 0.2$ & $4.2 \pm 0.2$ & $4.2 \pm 0.2$ & ns & $4.4 \pm 0.2$ & $4.4 \pm 0.1$ & $4.5 \pm 0.3$ & ns \\
\hline Small fish & $3.6 \pm 0.3$ & $3.6 \pm 0.2$ & $2.9 \pm 0.4$ & ns & $3.9 \pm 0.3$ & $3.8 \pm 0.2$ & $3.0 \pm 0.4$ & $\mathrm{~ns}$ \\
\hline Precooked foods & $3.4 \pm 0.3$ & $3.3 \pm 0.2$ & $3.3 \pm 0.4$ & ns & $2.8 \pm 0.3$ & $2.9 \pm 0.2$ & $2.9 \pm 0.4$ & ns \\
\hline Ready-made lunch box (Bento) & $3.4 \pm 0.2$ & $3.0 \pm 0.2$ & $2.9 \pm 0.4$ & ns & $3.3 \pm 0.3$ & $2.7 \pm 0.2$ & $2.9 \pm 0.4$ & $\mathrm{~ns}$ \\
\hline Fast food & $4.3 \pm 0.2$ & $3.8 \pm 0.2$ & $3.8 \pm 0.4$ & $\mathrm{~ns}$ & $3.8 \pm 0.3$ & $3.4 \pm 0.2$ & $3.6 \pm 0.4$ & ns \\
\hline \multicolumn{9}{|l|}{ Frequency ${ }^{2)}$} \\
\hline Milk and milk products & $4.1 \pm 0.2$ & $3.8 \pm 0.1$ & $3.1 \pm 0.2$ & $<0.01$ & $4.1 \pm 0.3$ & $3.5 \pm 0.2$ & $3.0 \pm 0.4$ & $<0.05$ \\
\hline Soybean and soybean products & $3.6 \pm 0.2$ & $3.6 \pm 0.2$ & $3.1 \pm 0.2$ & ns & $3.3 \pm 0.3$ & $3.5 \pm 0.2$ & $3.3 \pm 0.2$ & ns \\
\hline Vegetable & $4.4 \pm 0.2$ & $4.2 \pm 0.2$ & $4.2 \pm 0.3$ & ns & $4.0 \pm 0.2$ & $4.1 \pm 0.2$ & $3.8 \pm 0.3$ & ns \\
\hline Small fish & $3.1 \pm 0.2$ & $2.4 \pm 0.2$ & $2.2 \pm 0.5$ & $<0.05$ & $2.1 \pm 0.2$ & $2.0 \pm 0.2$ & $2.1 \pm 0.4$ & ns \\
\hline Precooked foods & $1.6 \pm 0.1$ & $1.8 \pm 0.1$ & $1.8 \pm 0.4$ & ns & $1.4 \pm 0.2$ & $1.4 \pm 0.1$ & $1.7 \pm 0.3$ & ns \\
\hline Ready-made lunch box (Bento) & $1.5 \pm 0.1$ & $1.5 \pm 0.1$ & $1.2 \pm 0.1$ & ns & $2.3 \pm 0.3$ & $2.2 \pm 0.2$ & $1.8 \pm 0.4$ & $\mathrm{~ns}$ \\
\hline Fast food & $1.8 \pm 0.2$ & $1.7 \pm 0.1$ & $1.7 \pm 0.2$ & $\mathrm{~ns}$ & $1.5 \pm 0.2$ & $1.4 \pm 0.1$ & $1.6 \pm 0.2$ & ns \\
\hline
\end{tabular}

Study subjects were separated into three groups according to their OSI, A; $\geqq 2.698, \mathrm{~B} ; 2.698>\sim \geqq 2.428, \mathrm{C} ; 2.428>$.

*Probability with Kruskal-Wallis test, ns means not significant.

${ }^{1)}$ Scored between 5 (like) and 1 (dislike).

${ }^{2)} 5$; everyday, 4 ; once 2 days, 3 ; once 3 days, 2; once a week, 1 ; not eat.

${ }^{3)}$ Mean \pm SE.

認められず，この両者の関連を明らかにするには，さら なる検討が必要と考えられた。

\section{3 ．食物摂取状況之骨量の関係}

OSI 值より区分した 3 群について主要食品の嗜好度, 摂取頻度を比較した（Table 3). その結果，牛乳・乳製 品に対して, 現在ならびに過去の嗜好度および摂取頻度 
において 3 群間に有意な差が認められ，牛乳・乳製品摂 取と骨量の関連性が示唆された. また, 小魚の過去の摂 取頻度においても 3 群間に有意差が認められた.

牛乳摂取と骨量との間の相関はこれまでにも多くの報 告が見られるが11),14),17), 一方, 相関を認めなかったと する報告もみられる10). 本研究では, Table 2 では調査 期間 3 日間のカルシウム摂取量と骨量の間に相関が認め られなかったが, Table 3 では牛乳・乳製品の嗜好度, 摂取頻度と骨量には関連性が認められた。これらの結果 の違いは, 栄養素摂取量調査結果は短期間の状況を示す がより長期の状況は必ずしも反映せず, 一方, 頻度調査 はより長期の食物摂取状況を反映することが関連したの ではないかと考えられた. さらに, カルシウムの供給源 は牛乳・乳製品だけでなくそれ以外の食品もあることも 両結果の不一致に関連したと考えられた.

牛乳以外の食品については，これまでに野菜・果物 ${ }^{22)}$ の摂取量と骨量の関連性が報告されているが, 本研究で はそのような関連性は認められなかった。

\section{4，学生と親における食物摂取状況の関連}

12 種類の食品に対する嗜好度および摂取頻度につい て, 現在の学生と親の相関を調べた (Table 4). その結 果, 嗜好度については, スナック菓子, インスタント食 品, ファーストフードのような比較的簡便な食品と, 大 豆・大豆製品に有意な相関が認められた．摂取量頻度に ついては, Table 3 において骨量との関連性が認められ た牛乳・乳製品に, 学生と親の相関が認められた. また,

Table 4 Correlation between students and their parents on the preference or eating frequency of foods

\begin{tabular}{lccccc}
\hline & \multicolumn{2}{c}{ Preference ${ }^{1)}$} & & \multicolumn{2}{c}{ Frequency $^{2)}$} \\
\cline { 2 - 3 } & $\mathrm{r}^{*}$ & $p^{* *}$ & & $\mathrm{r}^{*}$ & $p^{* *}$ \\
\hline Milk and milk products & 0.056 & $\mathrm{~ns}$ & & 0.372 & $<0.05$ \\
Soybean and soybean products & 0.399 & $<0.05$ & & 0.277 & $\mathrm{~ns}$ \\
Vegetable & 0.276 & $\mathrm{~ns}$ & & 0.512 & $<0.01$ \\
Meat & 0.330 & $\mathrm{~ns}$ & & 0.231 & $\mathrm{~ns}$ \\
Fish & 0.311 & $\mathrm{~ns}$ & & 0.007 & $\mathrm{~ns}$ \\
Small fish & 0.011 & $\mathrm{~ns}$ & & 0.259 & $\mathrm{~ns}$ \\
Seaweeds & 0.294 & $\mathrm{~ns}$ & & 0.474 & $<0.05$ \\
Mushrooms & 0.078 & $\mathrm{~ns}$ & & 0.370 & $<0.05$ \\
Snacks & 0.368 & $<0.05$ & & 0.467 & $<0.01$ \\
Precooked foods & 0.371 & $<0.05$ & & 0.297 & $\mathrm{~ns}$ \\
Ready-made lunch box (Bento) & 0.014 & $\mathrm{~ns}$ & & 0.083 & $\mathrm{~ns}$ \\
Fast food & 0.432 & $<0.05$ & & 0.428 & $<0.05$ \\
\hline
\end{tabular}

${ }^{1)}$ Scored between 5 (like) and 1 (dislike).

${ }^{2)} 5$; everyday, 4; once 2 days, 3 ; once 3 days, 2; once a week, 1 ; not eat.

${ }^{*}$ Correlation coefficients (Spearman correlation) and

** probability, ns means not significant.
Table 2 において摂取量が低いと示された食物繊維の供 給源になる野菜, 海藻, きのこ類についても, 学生と親 の摂取頻度に相関が認められた.さらに，簡便な食品で あるスナック菓子, ファーストフードにも学生と親の摂 取頻度に相関が認められた。

食生活における親の影響については，これまで十分な 研究があるとはいえない。これまでに，食品に対する嗜 好性が親と幼児では異なる ${ }^{23)}$, 学生の減塩意識や味覚は 親の影響を受ける24)などの報告があるが，食品嗜好度や 摂取頻度についての報告はあまりみられない. 本研究て は, 骨量との関連が示唆されている牛乳・乳製品や, 食 物䋐維の供給源になる食品類について, 女子学生の摂取 類頻度が親の影響を受けることを示唆する結果が見られ た、しかし，牛乳・乳製品に対する嗜好度は相関が見ら れず, またカルシウム給源である小魚の嗜好度, 摂取頻 度も相関が見られなかった。これらの結果から，学生の 食品嗜好性や摂取頻度に対する親の影響を明らかに示す には，今後さらなる研究が必要と考えられた．そのよう な研究はまた, 成長期の食生活環境のあり方と青年期に おける高い最大骨量の獲得との関連性について有益な情 報を提供するものと考えられる.

\section{5. 年歯令・身体状況および運動量と骨量の関係}

身長，体重，BMI などが骨量と相関関係にあること がこれまでに報告されている5，10),19)。本研究では Table 1 でみたようにやせのものが多く，それが骨量の低 下に反映しているのではないかと予想されたが，対象者 の年齢，抢よび身長，体重，BMIのような 身体状況とOSI值の間に，いずれも相関を 認めなかった（Table 5). 初経年齢, 初経後 の経過期間とOSI 値の相関を調べた結果， 初経年齢とは負の相関が，初経後の経過期間 とは正の相関が認められ，月経が骨の発育に 関連する可能性が示唆された.

対象者をOSI 值により区分したA，B，

Table 5 Correlation between OSI and age or physical characteristics

\begin{tabular}{lrc}
\hline & \multicolumn{1}{c}{$\mathrm{r}^{*}$} & $p^{* *}$ \\
\hline Age (years) & -0.105 & $\mathrm{~ns}$ \\
Height $(\mathrm{cm})$ & 0.108 & $\mathrm{~ns}$ \\
Weight $(\mathrm{kg})$ & 0.087 & $\mathrm{~ns}$ \\
BMI $\left.(\mathrm{kg} \mathrm{/} \mathrm{m})^{2}\right)$ & 0.007 & $\mathrm{~ns}$ \\
Age of menarche & -0.473 & $<0.01$ \\
Duration from menarche & 0.413 & $<0.01$ \\
\hline
\end{tabular}

*Correlation coefficients (Pearson correlation). **Probability, ns means not significant. 
Table 6 Age and physical characteristics in groups $A, B$, and C

\begin{tabular}{lcccc}
\hline & A & B & C & $p^{*}$ \\
\hline Age (years) & $19.3 \pm 0.2$ & $19.0 \pm 0.2$ & $18.9 \pm 0.2$ & $\mathrm{~ns}$ \\
Height (cm) & $160 \pm 2$ & $157 \pm 1$ & $160 \pm 2$ & $\mathrm{~ns}$ \\
Weight (kg) & $49.0 \pm 1.9$ & $49.4 \pm 1.0$ & $49.4 \pm 1.7$ & $\mathrm{~ns}$ \\
BMI $\left(\mathrm{kg} / \mathrm{m}^{2}\right)$ & $19.2 \pm 0.6$ & $20.0 \pm 0.3$ & $19.3 \pm 0.4$ & $\mathrm{~ns}$ \\
Age of menarche & $12.0 \pm 0.4$ & $12.5 \pm 0.2$ & $12.9 \pm 0.4$ & $\mathrm{~ns}$ \\
Duration from menarche & $7.13 \pm 0.47$ & $6.76 \pm 0.29$ & $6.11 \pm 0.56$ & $\mathrm{~ns}$ \\
\hline
\end{tabular}

Mean \pm SE.

*Probability with Kruskal-Wallis test, ns means not significant.

Table 7 Habit of exercise at present and past time in groups $A, B$ and $C$

\begin{tabular}{lcrrr}
\hline & A & B & \multicolumn{1}{c}{ C } & $p^{*}$ \\
\hline Habit of exercise (past) ${ }^{1)}$ & $2.4 \pm 0.2$ & $2.5 \pm 0.2$ & $2.0 \pm 0.3$ & ns \\
Steps with pedometer (present) & $11648 \pm 1338$ & $10004 \pm 615$ & $10103 \pm 259$ & ns \\
\hline Mean \pm SE. & & & \\
*Probability with Kruskal-Wallis test, ns means not significant. \\
1) Mean score between elementary school and high school. 4, everyday; 3, 3 $\sim 5$ days / week; \\
2, 1 2 days/week; 1, no exercise.
\end{tabular}

C群について，年齢，身体状況，月経状況を比較した (Table 6).その結果, 年龄, 身長, 体重, BMI, 初経 年齢, 初経後の経過期間のいずれの項目においても 3 群 間に有意差が認められなかった。

運動と骨の発育についても，これまで多くの報告がみ られる10),15) 17),19),20)。本研究では，A，B，C群の現 在の運動量および過去の運動習慣について比較した (Table 7). その結果，それらの間に有意差が認められ ず，運動と骨の成長との関連性は認められなかった，従 って本研究においては， 3 群間の骨の発育を比較するに あたって，身体運動の要因を考慮する必要はないと考え られた。

以上のような本研究の結果, 女子学生を骨量により 3 群に分けた場合, 栄養素等摂取量, 年龄, 身長, 体重, BMI, 初経年齢, 初経後の経過期間, 運動量にはいず れも 3 群間に有意差が見られず，牛乳・乳製品に対する 摂取頻度, 嗜好度, および小魚の過去の摂取頻度が女子 学生のより高い骨量に関連することが示された。

\section{4. 要 約}

1 ）女子学生 50 人の右踵骨骨量を超音波骨評価装置に より測定し, 音響的骨評価值（OSI）で表した. 対象者 の OSI の平均値は $2.619 \pm 0.241$ で, 老人保健法による スクリーニングのための判定基準の $97.1 \%$ あっった.

2 ）対象者を OSI 值で 3 群に区分して主要食品の摂 取頻度, 嗜好度を比較した結果, 現在ならびに過去の牛
乳の摂取頻度, 喏好度に有意差がみられ, 牛乳摂取と骨 量の関連性が示唆された．また，小魚の過去の摂取頻度 にも 3 群間に有意差が見られた.

3）食品の搘好度および摂取頻度について, 現在の学 生と親の相関を調べた結果, 大豆・大豆製品, スナック 菓子, インスタント食品およびファーストフードの嗜好 度, 牛乳·乳製品, 野菜, 海藻, きのこ類, スナック菓 子及びファーストフードの摂取頻度に相関が認められ た.しかし, 牛乳·乳製品に対する嗜好度, 小魚の嗜好 度，摂取頻度には相関が見られなかった。

4）OSI 值で区分した 3 群間について現在の栄養素等 摂取量, 年齢, 身長, 体重, BMI, 初経年齢, 初経後 の経過期間, 運動量を比較したが, いずれも有意な差が 見られなかった。

\section{文献}

1) Matkovic, V., Fontana, D., Tominac, C., Goel, P., Chesnut $\mathrm{CH}$ III: Factors that influence peak bone mass formation: a study of calcium balance and the inheritance of bone mass in adlescent females. Am. J. Clin. Nutr., 52, 878-888 (1990)

2) Theintz, G. E., Buchs, B., Rizzoli, R.: Longitudinal monitoring of bone mass accumulation in healthy adolescent: evidence for a marked reduction after 16 years of age at the levels of the lumbar spine and femoral neck in female subjects. J. Clin. Endo. Met., 75, 1060-1065 (1992)

3) Teegarden, D., Hoffman, K., McMurray, M.: Effects of dairy products on bone and body composition in pubertal girls. J. Paediatrics, 126, 551-556 (1995)

4) Merrilees, M. J., Smart, E. J., Gilchrist, N. L., Frampton, C., Turner, J. G., Hooke, E., March, R. L., Maguire, P.: Ef 
fects of dairy food supplements on bone mineral density in teenage girls. Eur. J. Nutr., 39, 256-262 (2000)

5） 戸田 歩，塚原典子，江澤郁子：閉経期 - 後期日本人女性 の骨密度に対する食生活および身体活動の影響. 日本栄養 · 食糧学会誌, 46, 387-394（1993）

6）健康·栄養情報研究会編：国民栄養の現状：平成12年厚生 労働省国民栄養調査結果, 第一出版, 東京 (2002)

7）江澤郁子 : 間違ったダイエットの骨への影響. 家政誌, 52, 1029-1034 (2001)

8) Hans, D., Dargent-Molina, P., Schott, A. M., Sebert, J. L., Cormier, C., Kotzki, P. O., Pouilles, J. M., Breart, G., Meunier, P. J.: Ultrasonographic heel measurements to predict hip fracture in elderly women: the EPIDOS prospective study. Lancet. 348, 511-514 (1996)

9) Hamanaka, Y., Yamamoto, I., Takada, M., Matsushita, R., Ota, T., Yuh, I, Morita, R.: Comparison of bone mineral density at various skeletal sites with quantitative ultrasound parameters of the calcaneus for assessment of vertebral fractures. J. Bone Miner. Metab., 17, 195-200 (1999)

10) Fehily, A. M., Coles, R. J., Evans, W. D., Elwood, P. C.: Factors affecting bone density in young adults. Am. J. Clin. Nutr., 56 579-586 (1992)

11）細川和美, 柳 久子, 川波公香, 田中キミ子, 小林 圭, 天貝 均, 戸村成男, 土屋 滋: 骨粗鬆症と食生活に関する 研究 : 若い頃の食生活との関連を中心に. 日本公衛誌, 43, 606-613 (1996)

12) Tsukahara, N., Sato, K., Ezawa, I.: Effects of physical characteristics and dietary habits on bone mineral density in adrescent girls. J. Nutr. Sci. Vitaminol., 43, 643-655 (1997)

13）土田賢一, 水嶋春朔, 高橋秀明, 三杉信子, 曾田研二 : 閉 経前女性における食生活習慣と食塩量. 日本公衛誌, 45, 121-128 (1998)

14) Teegarden, D., Lyle, R. M., Proulx, W. R., Johnston, C, C., Weaver, C. M.: Previous milk consumption is associated with greater bone density in young women. Am. J. Clin. Nutr., 69, 1014-1017 (1999)
15) Sasaki, M., Harata, S., Kumazawa, Y., Tita, R., Kida, K., Tsuge, M.: Bone mineral density and osteo sono assessment index in adolescents. J. Orthop., Sci., 5. 185-191 (2000)

16) Yamaguchi, J., Truman, G., Cameron, I. D.: Lifestyle factors affecting bone ultrasonometry of the calcaneus in Japanese women. Calcif. Tissue Int., 66, 43-46 (2000)

17）稲葉洋美, 酒井健介, 高齐みさお了, 山岸博之, 太田篤糸, 㝨田 勝 : $18 \cdot 19$ 歳女子大生の踵骨骨梁面積率に与える食生 活と運動経験の影響. 日本食生活学会誌, 12, 255-261 (2001)

18) Welten, D. C., Kemper, H. C. G., Post, G. B.: Weight bearing activity during youth is a more important factor for peak bone mass than calcium intake. J. Bone Miner. Res., 9, 10891096 (1994)

19) Hirota, T., Nara, M., Ohguri, M., Manago, E., Hirota, K.: Effect of diet and lifestyle on bone mass in Asian young women. Am. J. Clin. Nutr., 55, 1168-1173 (1992)

20) Hukuharu, M., Sato, J., Ohsawa, I., Oshida, Y., Kuriki, K., Shibata, K., Tamagawa, T., Nagaya, T., Fujiwara, N., Tokudome, S., Sato, Y.: Effects of lifestyle factors on ultrasonographically determined bone health in Japanese women. Public Health, 115, 146-151 (2001)

21）骨粗鬆症財団監修：老人保健法による骨粗鬆症予防マニュ アル (第 2 版), 日本医事新報社, 東京 (2000)

22) New, S. A., Robins, S. P., Campbell, M. K., Martin, J. C., Garton, M. J., Bolton-Smith, C., Grubb, D. A., Lee, S, J., Reid, D. M.: Dietary influences on bone mass and bone metabolism: Further evidence of a positive link between fruit and vegetable consumption and bone health. Am. J. Clin. Nutr., 71, 142-151 (2000)

23）田口田鶴子, 岡本洋子：幼児の食味嗜好性抢よび味覚閾值. 家政誌, 44, 115-121（1993）

24）田中順子, 田原モ下子, 山本由喜子 : 女子学生の塩味に対 する味覚特性と食物摂取状況. 日本食生活学会誌, 11, 353361 (2001) 